\title{
TÜRK BASININDA, ANA AKIM MEDYADA MÜLTECİ/SIĞINMACI TEMSILLI
}

\author{
Naciye Beril Ekşioğlu SARILAR \\ İstanbul Aydın Üniversitesi \\ berilsarilar@gmail.com \\ https://orcid.org/0000-0002-0641-4648
}

ÖZ

Ortadoğu ve Kuzey Afrika'da yaşanan “Arap Baharı”nın ardından iç savaşlar çıkmış, dünya İkinci Dünya Savaşı'ndan sonraki en büyük mülteci sorunu ile karşı karşıya kalmıştır. 2011 yılında Suriye' de başlayan savaşın ardından Haziran 2016 verilerine göre 13 milyon Suriyeli ülkesinden göç etmiş ve başka ülkelere sığınmak zorunda kalmıştır (www.aa.com.tr). Bu ülkelerden biri de Türkiye'dir. Bugün Türkiye'de Temmuz 2017 itibari ile 3,2 milyonu aşan Suriyeli yaşamaktadır (www.igamder.org.). Mülteci ve sığınmacı sorunsalı bugün tüm dünyanın en önemli problemleri arasında görülmektedir. Hayatta kalabilmek amaciyla ülkelerini terk eden mülteciler gittikleri ülkelerde de kabul/ret, hukuki belirsizlik, kültürel entegrasyon gibi farklı problemler yaşamaktadırlar. $\mathrm{Bu}$ sorunlar da kriminal olaylarla, politik söylemlerle medyanın gündemine yansımaktadır. Medya ise kültürel çeşitlilik konusunda kamuoyu algısını etkilemektedir. Bu durumda Türkiye'de basının mülteci/sığınmacı konusunu nasıl ele aldığı büyük bir önem kazanmaktadır. Bu nedenle 1.07.201717.08.2017 tarihlerindeki internet sitelerinde çıkan sığınmacı/mülteci haberlerine içerik ve eleştirel söylem analiziyle bakılmıştır. Bu doğrultuda araştırmada mülteci/sığınmacı hangi haber içerikleriyle ele alınmıştır, "bu haber içerikleri kamuoyunda nasıl bir algı oluşturabilir" sorularına cevap aranacaktır.

Anahtar Kelimeler: Mülteci, gö̧̧, entegrasyon, gazetelerin internet siteleri, söylem 


\title{
REPRESENTATION OF REFUGEE/IMMIGRANT IN TURKEY'S PRESS AND MAINSTREAM MEDIA
}

\begin{abstract}
After the Arab Spring in the Middle East and North Africa, outbreaks of the civil war occurred and the world was faced with the biggest refugee crisis after the Second World War. According to June 2016 data, 13 million Syrians migrated and were forced to take refuge after the outbreak of war in Syria in 2011(www.aa.com.tr). Turkey is one of the shelter countries. Over 3. 2 million Syrians are living in Turkey as of July 2017 (www.igamder.org.). The refugee crisis is one of the major problems in all over the world. Refugees, who leave their countries for survival, face problems such as admittance/rejection, legal disability, and cultural integration. These problems are reflected in media with criminal cases and political discourses. Media is influencing the perception of public opinion in the case of cultural integration. In this case, the approach of media to refugee crisis gains importance. How does media in Turkey deal with cultural differences? News in the matter of refugee crisis published on Newswire in between 1.07.2017-17.08.2017 was examined with the analytical approach of content and critical discourse analysis. News about refugees is dealt up to which content, "what kind of perception can this news create in public opinion" are questions to be answered accordingly on this research.
\end{abstract}

Keywords: Refugee, immigrant, integration, Newswire, discourse

\section{GİRIŞ}

2010 yılında Arap ülkelerinde başlayan protesto hareketleri iç çatışmalara, hatta bazı ülkelerde iç savaşa dönüşmüştür. Bu ülkelerden biri de Türkiye'nin sınır komşusu olan Suriye'dir. Suriye'deki iç savaş etnisite, dini ve siyasi farklılıklar nedeniyle tetiklenmiş sonuçta milyonlarca Suriyeli başka ülkelere iltica etmek zorunda kalmışlardır. Ülkelerinden kaçan Suriyeliler nedeniyle Türkiye büyük bir mülteci akınına uğramıştır. 2011 yılında 10 bin kişiyle başlayan göç, Temmuz 2017 itibariyle 3 milyon 69 bin 963 kişiye ulaşmıştır. Hacettepe Üniversitesi Göç ve Siyaset Araştırmaları Merkezi’ne göre Türkiye sınırlarının içinde 230 bin civarında kayıtsız Suriyelinin olduğu da söylenmektedir (www.dw.com). 10 y1l içinde nüfuslarının beş milyon olacağı öngörülen Suriyelilerin bugün Türkiye nüfusuna oranı yüzde 4'e yakındır.

Hayatta kalabilmek adına tehlikeli yolculukları, açlı̆ğ, sefaleti göze alan bu insanların Türkiye'deki medya temsilleri yadsınamaz derecede önemli bir konudur. Zira gün geçtikçe Türkiye'deki Suriyelilerin kalıc1lık eğilimleri artmakta, ülkeye intibakları ve yaşanılan süreçlere dâhil edilmeleri kaçınılmaz bir gerçek olarak karşımıza çıkmaktadır. Başlangıçta Türk hükümeti göç eden 
Suriyelileri geçici olarak tanımladıysa da bugün gelinen noktada Cumhurbaşkanı dâhil hükümet yetkilileri mültecilerin kalıcı olduklarını vurgulamaya başlamışlardır. Artık kalıcı mı, gidici mi sorularını sormak yerine sığınmacıların ülkeye entegrasyonunun sağlanmasının önemli olduğu görüşü ortak bir mutabakat haline gelmiştir. Economist dergisi "Yeni Komşular" başlıklı makalede "Türkiye mültecilere bakıyor, ancak entegre etmeyi başaramıyor", "Suriyeliler sürekli en alt sınıf olarak kalırsa, ülke sorun yaşayabilir" yorumunda bulunmuştur. Makalede Avrupa'da göç karşıtı partilerin mülteci korkusunu oya çevirmeye çalışırken, Türkiye'de hiçbir partinin bunu yapmadığını ancak her şeye rağmen kamuoyunda mültecilere karşı sert bir tutum gelişmeye başladığının altını çizmiştir (www.bbc.com). Economist'in öne sürdüğü gibi Türk medyasında mültecilerin dâhil olduğu toplumsal gerilim haberleri son aylarda sıç̧a yer bulmaya başlamıştır. Bu konuyla ilgili olarak Başbakan yardımcısı Türk halkına seslenerek "Hoşgörüyü elden bırakmayalım." demiş, Başbakan Binali Yıldırım ise misafirperverliğe laf getirecek davranışlardan kaçınılması gerektiğini söylemiştir. Yıldırım sığınmacılara da "Suç işleyen kendini sınır dışında bulur." uyarısında bulunmuştur. İçişleri Bakanı "Suriyelilerin karıştıkları olayların Türkiye'deki toplam asayiş olaylarına oranı 2014-2017 yılları arasında yüzde 1,32 ve bu olayların büyük kısmı kendi aralarındaki anlaşmazlıktır." (dw.com) dese de medyada sığınmacı/mülteci temsilinin kamuoyu algısını önemli ölçüde etkilemekte/şekillendirmekte olduğu görülmektedir. Bu sorunsaldan yola çıkarak Türk medyasındaki mülteci/sığınmacı temsilleri irdelenecektir; bu çerçevede ana akım medyadaki iki gazetenin internet sitesi örneklem olarak seçilmiştir. Çalışmada 1.07.2017- 17.08.2017 tarihleri aralığında bu iki gazetenin internet sitelerinin sığınmacıları konu eden haber metinleri içerik ve söylem analiziyle irdelenecektir. Öncelikle mülteci/sı̆̆ınmacı terminolojisine bakmak gerekir

\section{MÜLTECİ/SIĞINMACI KAVRAMI}

Uluslararası hukukta mülteci "refugee", sığınmacı "asylumseeker", göçmen "immigrant" terimleriyle yer almaktadır. Uluslararası hukukta mülteci "1rk1, dini, tabiiyeti, belli bir sosyal gruba mensubiyeti veya siyasi düşüncesi nedeniyle zulme uğrayacağından haklı sebeplerle korktuğu için vatandaşı olduğu ülkenin dışında bulunan ve bu ülkenin korumasından yararlanamayan ya da söz konusu korku nedeniyle yararlanmak istemeyen her şahıs" şeklinde tanımlanmaktadır (Cenevre sözleşmesi Madde 1A(2)). Bir başka deyişle, yaşayamadıkları vatanlarını terk edip, başka bir ülkeden sığınma talep edip, o ülke tarafından kabul edilen insanlara "mülteci" denmektedir (www.danistay.gov.tr).

Sığınmacı ise mülteci statüsüne talip ancak resmi olarak uluslararası koruma henüz alamamış kişilere denir. Yani sığınmacılık, mültecilik statüsünün bir önceki aşamasıdır. Ancak şunu özellikle belirtmek gerekir ki, mülteci statüsünü henüz alamamış olsalar da sığınmacılar geldikleri ülkelere kendi istekleri 
olmadan zorla gönderilemezler, onların da hakları sonuna kadar korunmak zorundadır. Çok sık kullanılan göçmen kelimesi bu anlamda mülteci/sı̆̆ınmacı terimlerinden ayrılır. Çünkü göçmenlik eğitim ve çalışma gibi ekonomik nedenlerle, daha iyi bir yaşam kurmak adına ülkesinden başka ülkelere göç eden insanları tanımlamak için kullanılır. Göçmenler için ülkesindeki baskı/zulüm gibi faktörlerden kaçış durumu söz konusu değildir.

Mültecilerin hukuki statüsünü belirleyen BM Cenevre Sözleşmesi 1951 tarihindeki konferansta kararlaştırılarak 1964 yılında yürürlüğe girdi. Ancak Mülteciler Sözleşmesi sadece İkinci Dünya Savaşı sonrası Avrupalı mülteciler için geçerliydi. 1967'deki ek protokolle sözleşmenin hem zaman hem de coğrafi açıdan kapsamı genişletilmiş oldu. Türkiye bu sözleşmeye taraf olmasına rağmen, sözleşmenin ilk halindeki coğrafi sınırlama ilkesini sürdürmeyi seçmiştir. Özetle Türk hukuk sistemi Avrupalı olmayan mültecilere mülteci statüsü tanımamaktadır (www.igamder.org). Türk hükümeti Avrupa ülkeleri dışından gelip koruma talep eden kişileri "sığınmacı" olarak tanımlamaktadır. Ancak Türkiye'de ister sığınmacı ister mülteci olsun uygulamada her iki gruba da aynı yükümlülükler uygulanmaktadır.

Arap Baharı ile Türkiye'ye başlayan yoğun göç trafiği, Türk hukuk sisteminde statülerin tanımlanması ihtiyacını doğurmuştur. Bu yüzden 2013 yılında 6458 sayılı Yabancılar ve Uluslararası Koruma Kanunu kabul edilmiştir. Buna göre, Avrupa'dan gelenlere "mülteci", Avrupa dışından gelenlere "şartlı mülteci" denmiştir. Yine aynı kanunda "mülteci" ve "şartlı mülteci" konumlarının yanına "ikincil koruma statüsü" denilen bir statü daha eklenmiştir, bu da mülteci ve şartlı mülteci olamayanlara verilmiş bir tanımlamadır. Bugün Türkiye 'deki Suriyeliler "şartlı mülteci" konumundadirlar (http://akademikperspektif.com/2015/02/23/turkiyedekisuriyelilerin-hukuki-statusu-uzerine-bir-calisma/).

6458 sayılı yasa Türkiye'nin ilk iltica yasasıdır. Yasa ile yabancılara ilişkin vize alma zorunluluğu, ikamet izni, vatansızların ve mültecilerin hukuki durumu, Göç İdaresi Genel Müdürlüğünün teşkilat yapısı gibi konular düzenlenmiş ve yabancılar hukuku mevzuatı tek yasada toplanmıştır (http://www.ankarabarosu.org.tr/siteler/ankarabarosu/hgdmakale/20142/31.pdf). Suriyeli sığınmacılar "geçici koruma" statüsüne alınmışlardır. Buna göre: açık sınır politikası ile ülke topraklarına kabul, geri göndermeme ilkesi, gelen kişilerin temel ve acil ihtiyaçlarının karşılanması yasal çerçeveye alınmıştır. 
Sığınmacıların bir ülkeye iltica etmeleri sorunların hallolduğu anlamına gelmemekte, sığınmacılar bu kez de toplumsal kabul problemiyle savaşmak zorunda kalmaktadırlar. Ülkede olan ekonomik krizin veya toplumsal gerginliklerin altında sığınmacıların etkisinin aranması tesadüfi değildir. Sığınmacılar iltica ettikleri ülkelerde eğitim, dil, hukuki, sağlık, barınma, çalışma şartları, güvenlik ve uyum sorunları yaşamaktadırlar. Türkiye'de hala etkin bir mülteci politikasının olmadığı açıktır. Bu da mültecilerin Türkiye'de ciddi bir uyum sorunu yaşamalarına ve temel haklarını karşılayamamalarına neden olmaktadır. Sonuçta özsaygısını yitiren ve gittikleri ülkedeki halkın yaşam koşullarına sahip olamayan mülteciler ile yerel halk arasında çatışmaların çıkması, bu grupların yasal olmayan yollar ile durumlarını iyileştirmeye çalışması gibi problemlerin ortaya çıkması kaçınılmaz olabilmektedir. İşte bu çatışmanın doğurabileceği kaotik ortamı önlemek için medya profesyonellerinin ürettiği medya ürünlerindeki temsil büyük önem kazanmaktadır.

\section{MEDYADA KÜLTÜREL KIMLÍKLERIN TEMSILLERI}

Medya temsilleri denince akla imajlar, anlatılar gelir ve bu temsiller haber metinleri, görseller, reklamlar, bloglar, sosyal medya araçları gibi içerikler üzerinden üretilmektedir. Temsil aslında içeriğin yeniden inşasını anlatmaktadır, gerçekliğin salt kendisi değildir. Haber ve gerçeklik arasındaki ilişki sıkıntılı ve tartışmaya açıktır. Temsil seçme, ötekini ayrıştırma/dışlamayı ihtiva eder. Kamuoyunda bütünleşme, değerlerin yaratılmasında, gündelik hayatı tanımlamada medya temsilleri önemli bir role sahiptir. Temsilde ideoloji, başat bir konumdadır. Medya temsilleri farklı türler cinsiyet, ,rk, etnisite gibi konularda eşitsizlik ve adaletsizliklerin yeniden üretimini kapsamaktadır. Dışlama, klişeler üretme, asimile etme ve ötekileştirme stratejileri ile ideolojik anlamlar üretilmektedir (Şen, 2016: 233).

Eleştirel yaklaşıma göre toplumda azınlık gruplarının medya temsilleri ile gerçek hayatta neden olduğu sonuçlar arasında ilişki vardır. Bu ilişki şu şekilde tanımlanır: "Tek başına bir metin oldukça önemsizdir: Medyanın etkisi, nedensellik ve faillik konularını ele almanın ve okuyucuyu konumlandırmanın vb. belirli şekillerinin tekrarı aracılığıyla birikerek oluşur" (Fairclough, 2001: 54). Van Dijk, söylemin ideolojinin yeniden üretiminde önemli olduğunu vurgularken, metin çözümlemelerinin buna göre yapılması gerektiğini belirtmiştir. Basın ve televizyonlardaki söylem tipi aynı anda birçok kişiye ulaşmakta ve çok etkin olmaktadır (Dijk, 2005: 353).

Eleştirel yaklaşımlar mültecilerin/sığınmacıların medyadaki temsillerini o ülkenin siyasi, ekonomik ve kültürel yapılarıyla ilişkilendirirler. Van Dijk Avrupa' da yaşayan göçmenler hakkında ayrımcı/ırkçı söylemin temsiline ilişkin dört başlık belirlemiştir: "Onlar farklıdır", "Olumsuz eylemlerde yer alırlar", 
"Sosyal-ekonomik menfaatlerimizi tehdit ederler" ve "Uyum sağlayamazlar" (Efe, 2015: 11). Bu temsiller bazen hükümetin bazen de muhalefetin dilinde siyasi/ideolojik çatışmanın nesnesi haline gelirler. Mülteci/sığınmac1/göçmen politikaları medyaya yansıyan bu temsiller aracılığıyla şekillenir.

King ve Wood, mültecilerin gittikleri ülkelerde siyasetin malzemesi olacaklarını, bunun da medyaya "öteki", "istenmeyen", "suçlu" imgeleriyle yansıyacağını, bu yüzden medyanın mültecilerin sesini duyurmada olumlu ancak ırkçı davranışların oluşmasında olumsuz olacağını vurgulamıştır (http://ozgurlukarastirmalari.com ). Medyanın, kamuoyunun algısının oluşmasındaki etkisi günümüzde inkâr edilemez bir gerçektir. Zira medyanın gündemi belirleme gücü de vardır. Sadece haber metinlerinde kullandığ veriliş sıklığ da kamuoyundaki algıyı etkilemektedir. Medya kamuoyuna sadece bir olayın neden önemli olduğunu anlatmakla kalmaz aynı zamanda kamuoyuna o olay hakkında nasıl, ne düşünmesi gerektiğini söylemekte ya da tam tersine kamuoyu tarafından görmezden gelinmesini sağlamaktadır. Eleştirel söylem analizinin en ünlü isimlerinden Van Dijk, "Söylem tiplerini, başlıkları, enformasyon miktarını ve başlığını, konuların seçimini ya da sansür edilmesini ve retorik işlemlerin doğasını belirleyen sembolik seçkinler ve onların söylemleridir." demiştir. Van Dijk'e göre haberler "sentaktik" ve "semantik" olarak incelenmelidirler. Sentaktik, cümlelerin gramatik yapılarını; semantik, cümlelerin anlamını ifade etmektedir. Söylemin ideolojinin yeniden üretimindeki rolünü belirten Dijk, kullanılan cümlelerin kısa ya da uzun olması, etken ya da edilgen olması, art arda gelen cümlelerin birbiriyle ilişkisi, haberin ideolojisini ortaya çıkarmaktadır. Kamuoyunun haber metinlerinde en çok hatırladıklarının özet, başlık ve giriş paragraflarında yer aldığını belirtmektedir (Tarhan, 2016:313). Bu yüzden yapılan çalışmada Van Dijk 'in Eleştirel Söylem Analizi Yöntemindeki gibi, mültecilerle ilgili haberlerin başlık, spot ve haber metin çözümlemeleri yapılmıştır.

\section{MÜLTECI HABERLERINDE ETIKK KRİTERLER}

"Medyanın toplumsal katılımdaki rolünü desteklemek" amacıyla 2005 y1lında British Council'in BBC World Service Trust (WST) ile bir çalışma yapmış buna ulusal ortak olarak 2006 yılında Türkiye Gazeteciler Cemiyeti de katılmış, mülteci haberlerinde etik kodları içeren bir kılavuz hazırlanmıştır (www.cocukvakfi.org.tr). Projede 4 ulusal gazetede, farklı toplumsal haberler içerik analiziyle incelendiğinde dezavantajlı grupların temsiliyle ilgili yapılan yanlışlar tespit edilmiş, bunların üzerinden yola çıkarak medyadaki meslek ilkelerinin iyileştirilmesi hedeflenmiştir. İşte bu çalışmalardan biri de "Kültürel farklılıklar ve toplumsal barışın sağlanmasında medyanın rolü" başlığıyla ele alınmıştır. Buradan yola çıkarak hazırlanan "Medya ve Çeşitlilik Kılavuzu" na göre "Toplumda rrk, etnik köken ve dini inanç temelinde tanımlanan kültürel 
çeşitliliklere sahip grupların var olma ve kendini ifade etme hakkını gerçekleştirebilmesi, bu grupların ayrımcılığa uğramaksızın, toplumsal barışı güçlendirme yönünde temsili için, iyi niyetle ve üst düzeyde çaba göstermeyi” medyanın hedef haline getirmesi gerektiği vurgulanmıştır. Bunu yaparken medyanın barış, demokrasi, insan hakları ve çoksesliliğe, farklılığa saygı kavramlarından yola çıkması gerektiği hatırlatılmıştır. Medya kuruluşlarına düşen görevler şu şekilde sıralanmıştır:

Düşünce ve ifade özgürlüğü de dikkate alınarak kültürel çeşitlilik konuları işlenirken kurum içi öz denetim mekanizmaları devreye mutlaka sokulmalıdır. $\mathrm{Bu}$ doğrultuda kurum içinde eğitim programları düzenlenmeli ve çalışanlarda etik konusuna karşı bir farkındalık yaratılmalıdır. Medya kuruluşları ırkçılığa, yabancı düşmanlığına yol açacak önyargılardan kaçınmalıdır. Tam tersine toplumdaki hoşgörüsüzlükle mücadele etmelidir. Bir kültürel grubu diğerine göre üstün gösterecek yayınlar yapılmamalıdır. Medya çalışanları, farklı kültürlerden gelenlerin eğitim, sağlık, barınma, güvenlik ve istihdam konularına özen göstermeli, bunları yaptıkları haberlerle kamuoyuna aktarmalı, eşit hak taleplerini dile getirmelidirler.

Medya çalışanları haberle doğrudan ilgisi yoksa haber metninde ırk, etnik köken, din ve mezhep belirtmemelidir. $\mathrm{Bu}$ özellikler olumsuz vurgu olarak kullanılmamalıdır. Gazeteciler toplumda yaygın hale gelmiş kalıp yargılardan uzaklaşmalı, bunlar haberin metninde ve görselinde yer almamalıdır.

Kültürel farklılığa sahip gruplar ayrımcı, kışkırtıcı veya sansasyon yaratıcı bir dil ile anlatılmamalıdır. Bir ülkede "azınlık" konumunda olanların farklılıklarını ve yurttaşl1k statülerini sorgulayan, reddeden, suçlayan her türlü medya ürününe hayır denmelidir. Tek bir kişiden yola çıkarak yaşanan olumsuz olay tüm topluluğa mal edilmemelidir. Farklı kültürel kimlikten gelen uzmanlara medyada yer verilmelidir (www.tgc.org.tr).

\section{ARAŞTIRMA YÖNTEMI}

Türkiye'de sığınmacı/mülteci terimleri hukuki olarak farklı zeminlere otursa da medyadaki kullanımı ortak bir anlam ifade etmektedir. Bu yüzden yapılan çalışmada da mülteci/sığınmacı ortak bir ifadeyi karşılamaktadır. Bu çalışmada, mülteci/sığınmacı temsillerinin sıklı̆̆ı, hangi içeriklerle medya metinlerinde söz edildiklerinin tespiti ayrıca mülteci/sığınmacı haber başlıklarının belirlenmesi, haber spotlarındaki ve haberin alt metinlerindeki sığınmacı temsillerindeki bakış açılarının tespit edilmesi gibi konuların incelenmesi hedeflenmiştir. Araştırmada 1.07.2017 ile 17.08.2017 tarihleri arasındaki mülteci haberleri Hürriyet ve Sabah internet sitelerindeki haber içeriklerine bakılarak analiz edilmiştir. Haberlerde özellikle sığınmacı sorunlarına ve Türkiye'deki sığınmacı kökenli yerel halkın sorunlarına odaklanılmıştır. Haber içerikleri ana başlıklar halinde: mültecilerle 
ilgili ulusal ve yabancı kaynaklı siyasi açıklamalar, sığınmacı/mülteci adli vakaları, yerel halkın mülteci yardımları, mülteci sorunları, mültecilerin kaçak yolculuk haberleri, yabancı ülkelerdeki mültecilere dair haberler, mülteci kökenli yerel halk sorunları ve yaşanan toplumsal gerilim haberleri, medyanın bizzat medyay1 "nefret suçu" ile itham ettiği haberler, mültecilere dair günlük yaşam haberleri, mültecilerle ilgili devlet politikasını eleştiren haberler olarak irdelenmiştir. Sığınmacı sorunları da alt başlıklar olarak: barınak kökenli sorunlar (kentler veya kamplar), işsizlik, dil problemi, sağlık, eğitim ve güvenlik sorunları olarak ayrılmıştır. Mültecilerin karıştıkları adli olaylara dair haberler yangın, cinayet, tecavüz ve taciz vakaları vs. yardım haberleri ise hoşgörü ve misafirperverlik temalı, mültecileri iyileştirme çabalı projeler olarak yine alt başlıklara bölünmüştür. Şunu da belirtmek gerekir aynı haber hem dil sorununu hem güvenlik sorununu içerebilir. $\mathrm{Bu}$ durumda haber iki kategoride de değerlendirilecektir.

Hürriyet gazetesinin internet sitesinde incelemenin yapıldığ 1.07 .2017 ile 17.08.2017 tarihleri arasında mültecilerle ilgili 51 haber, Sabah gazetesinin internet sitesinde ise 17 haber yayınlanmıştır. Haberlerin içeriklerinin dökümü şu şekildedir:

Tablo 1. Haberlerin İçeriklerine göre Dağılımı

\begin{tabular}{|l|l|}
\hline HABER İÇERİKLERİ & YAYINLANMA SAYISI \\
\hline Siyasetçilerin Açıklamaları & 11 (On bir) \\
\hline Yardım Haberleri & 10 (On) \\
\hline Mültecilere Dair Yaşam Haberleri & 9 (Dokuz) \\
\hline Mültecilerin Kaçış Haberleri & 9 (Dokuz) \\
\hline Mültecilerin Sorunları & 9 (Dokuz) \\
\hline Yabancı Ülkelerdeki Mültecilerin Haberleri & 8 (Sekiz) \\
\hline Adli Vaka Haberleri & 7 (Yedi) \\
\hline $\begin{array}{l}\text { Yerel Halk ve Mülteciler Arasında Gerginlik } \\
\text { Haberleri }\end{array}$ & 6 (Altı) \\
\hline Medyanın “Nefret Suçu” İşlediği Haberler & 3 (Üç) \\
\hline Devlet Politikalarına Yönelik Eleştiri Haberleri & 2 (İki) \\
\hline
\end{tabular}


Tablo 2. Konularına göre Haberlerin Tekrarlanma Sayısı

\begin{tabular}{|l|l|}
\hline HABER İÇERİKLERİ & $\begin{array}{l}\text { KONULARINA GÖRE HABERLERİN } \\
\text { TEKRARLANMA SAYISI }\end{array}$ \\
\hline Adli Vaka Haberleri & $\begin{array}{l}\text { 6 (Altı) Tecavüz Haberi, 1 (Bir) Ölümlü Yangın } \\
\text { Haberi }\end{array}$ \\
\hline $\begin{array}{l}\text { Mültecilere Yardım } \\
\text { Haberleri }\end{array}$ & $\begin{array}{l}\text { 4 (Dört) Türk Halkının Konukseverliği Haberi, 6 } \\
\text { (Altı) Mültecilere Yardım Projeleri Konulu Haber }\end{array}$ \\
\hline $\begin{array}{l}\text { Mülteci Sorunlarını } \\
\text { İçeren Haberler }\end{array}$ & $\begin{array}{l}\text { 6 (Altı) Eğitim, 6 (Altı) İşsizlik, 6 (Altı) Dil } \\
\text { Problemi, 5 (Beş) Barınma, 5 (Beş) Sağlık, 1 } \\
\text { (Bir) Güvenlik Sorununa Dair Haber }\end{array}$ \\
\hline
\end{tabular}

Tablo 3. Mültecilerle İlgili Haber İçeriklerinin Gazetelere göre Dağılımı

\begin{tabular}{|l|l|l|}
\hline $\begin{array}{l}\text { HABER İÇERIKLERINIIN } \\
\text { GAZETELERE GÖRE } \\
\text { DAĞILIMI }\end{array}$ & $\begin{array}{l}\text { HÜRRIYET } \\
\text { GAZETESI } \\
\text { İNTERNET SİTESİ }\end{array}$ & $\begin{array}{l}\text { SABAH GAZETESİ } \\
\text { İNTER SITESİ }\end{array}$ \\
\hline Siyasetçilerin Açıklaması & 8 (Sekiz) & 3 (Üç) \\
\hline Adli Vaka Haberleri & 4 (Dört) & 3 (Üç) \\
\hline Yardım Haberleri & 8 (Sekiz) & 2 (İki) \\
\hline Mültecilerin Sorunları & 9 (Dokuz) & Yok \\
\hline $\begin{array}{l}\text { Yabancı Ülkelerdeki } \\
\text { Mülteci Haberleri }\end{array}$ & 7 (Yedi) & 1 (Bir) \\
\hline Mültecilerin Kaçış Haberleri & 6 (Altı) & 3 (Üç) \\
\hline $\begin{array}{l}\text { Medyanın Mülteciler } \\
\text { Üzerinden Medyayı } \\
\text { Suçladığı Haberler }\end{array}$ & Yok & 3 (Üç) \\
\hline $\begin{array}{l}\text { Mültecilere Dair Yaşam } \\
\text { Haberleri }\end{array}$ & 6 (Altı) & 3 (Üç) \\
\hline $\begin{array}{l}\text { Yerel Halk ve Mülteciler } \\
\text { Arasındaki Gerginlik } \\
\text { Haberleri }\end{array}$ & 6 (Altı) & Yok \\
\hline $\begin{array}{l}\text { Mültecilere Dair Devlet } \\
\text { Politikalarının Eleştirildiği } \\
\text { Haberler }\end{array}$ & 2 (İki) & Yok \\
\hline
\end{tabular}

Rakamlara bakıldı̆̆ında Hürriyet gazetesinin mülteci konusunu olumlayan/olumsuzlayan haberlerle daha sik internet sayfasına taşıdığı görülmektedir. 


\section{Başlıklar ve Spotlar (Haberin Giriş Özeti)}

Gerek yazılı basında gerek görsel basında haber söyleminin önemli bölümünü başlıklar ve spotlar oluşturmaktadır. Aslında bu iki bölüm haberin küçük bir özeti gibidir. Dijk de bunu şu sözlerle destekler: haberin en çok hatırlanan noktaları özet, başl1k ve giriştir (Tarhan, 2016:313). Buradan yola çıkarak araştırmada genelde incelenen haberlerin başlıklarına ve spotlarına bakılmaya ve analiz edilmeye gayret edilmiştir. Ancak bazı haberlerde metnin alt satırlarında dikkat çeken noktalar da incelenmiştir.

Mültecilerin, Avrupa'ya geçmek maksadıyla kullandıkları emniyetsiz deniz ve kara araçlarında yaşadıkları facia ve yakalanma olaylarına ilişkin haberlere Hürriyet ve Sabah gazetelerinin internet sitelerinde sıkça rastlamaktayız:

Tablo 4. Mültecilere Dair "Facia ve Yakalama" Haberlerinin Dağılımı

\begin{tabular}{|l|l|}
\hline BAŞLIKLAR & $\begin{array}{l}\text { GAZETELERİN İNTERNET } \\
\text { SİTELERINDE HABERLERIN } \\
\text { YAYINLANDIĞI TARİH }\end{array}$ \\
\hline Muğla'da 58 Mülteci Yakalandı & 30 TEMMUZ 2017, Hürriyet \\
\hline $\begin{array}{l}\text { İzmir'den Yunanistan'a Geçmek } \\
\text { İsteyen 19 Mülteci Yakalandı }\end{array}$ & 29 TEMMUZ 2017, Hürriyet \\
\hline İzmir'de 76 Mülteci Yakalandı & 28 TEMMUZ 2017, Hürriyet \\
\hline $\begin{array}{l}\text { İzmir'den Yunanistan'a Geçme } \\
\text { Yakalılındıdıki 64 Mülteci }\end{array}$ & 26 TEMMUZ 2017, Hürriyet \\
\hline $\begin{array}{l}\text { Sivas'ta Yol Uygulamasında 51 } \\
\text { Mülteci Yakalandı }\end{array}$ & 17 TEMMUZ 2017, Hürriyet \\
\hline $\begin{array}{l}\text { Demir Yüklü Tırdan Ağır Yaralı 3 } \\
\text { Mülteci Çıktı }\end{array}$ & 10 TEMMUZ 2017, Hürriyet \\
\hline Mülteci Faciası: 7 Ölü & 29 TEMMUZ 2017, Sabah \\
\hline $\begin{array}{l}\text { Libya Açılarında 712 Mülteci } \\
\text { Kurtarıldı }\end{array}$ & 26 TEMMUZ 2017, Sabah \\
\hline
\end{tabular}

$\mathrm{Bu}$ haberlerdeki başlıklara baktığımızda; mülteci, yakalandı, kurtarıldı, ölü kelimelerinin anahtar kelimeler olduğunu, sadece yer isimlerinin ve mültecilerin sayılarının değiştiğini görmekteyiz. Ana akım medya ürünleri "mülteciler" derken soyut bir grubu ifade ediyor ve bu grubun üyeleri genellikle sadece adları 
bir cinayete, bir suça karıştı̆̆ında ya da kurban olduğunda belli bir kimlik kazanabiliyor. Medyanın bu söylemle mültecileri bir anlamda kimliksiz hale getirdiği ve "bizden" farklı olan "öteki" ne büründürdüğü dikkat çekmiştir. Mültecilerle ilgili "genel" ifadeye haberlerin neredeyse tamamında rastlanmaktadir.

Tablo 5. Mültecilerle İlgili Adli Vaka Haberlerinden Örnekler

\begin{tabular}{|l|l|}
\hline BAŞLIKLAR & $\begin{array}{l}\text { GAZETELERİN İNTERNET } \\
\text { SITELERINDE HABERLERIN } \\
\text { YAYINLANDIĞI TARİH }\end{array}$ \\
\hline $\begin{array}{l}\text { 16 Yaşıındaki Kıza Cinsel Taciz } \\
\text { Şüphisi Kadın ile Cinsel İstismar } \\
\text { Şüphelisi Erkeğe Gözaltı }\end{array}$ & 16 AĞUSTOS 2017, Hürriyet \\
\hline $\begin{array}{l}\text { Samsun'da Biri Kadın İki Kişinin } \\
\text { Cinsel Sapıklığı Şok Etti }\end{array}$ & 16 AĞUSTOS 2017, Sabah \\
\hline
\end{tabular}

Haberlerin başlıklarına baktığımızda Hürriyet'in yaşanılan olaya daha ihtiyatlı durduğunu "şüpheli” sözcüğ̈̈ ile görmekteyiz. Sabah'ın spotunda ise olay “cinsel sapıklık" olarak verilmiş ve "şok etti" denilerek kamuoyunda merak uyandırmak ve olayın toplumsal boyutunun büyüklüğü vurgulanmak istenmiştir. Bu iki kaynağın haber spotlarında ise tacizin mekânı "banyo" ya vurgu yapılarak pornografik bir çağrışım hedeflenmiştir. Haberdeki mağdur ve cinsel istismar şüphelilerinin Iraklı mülteciler oldukları yine ilk paragrafta verilmiştir.

Tablo 6. Mültecilerle İlgili Günlük Yaşama Dair Haber Örneği

\begin{tabular}{|l|l|}
\hline BAŞLIKLAR & $\begin{array}{l}\text { GAZETELERİN İNTERNET } \\
\text { SITTELERINDE HABERLERIN } \\
\text { YAYINLANDIĞI TARİH }\end{array}$ \\
\hline Pet Şişeler Can Yeleği Oldu & 16 AĞUSTOS 2017, Hürriyet \\
\hline
\end{tabular}

Spotun altındaki giriş paragrafında “...kıyıya vuran mülteci cesetleri gündemden düşmezken, çoğu yüzme bilmeyenlerin umut yolculuğu genelde kötü haberlerle sonlanırken, İzmir'de yaşayan Suriyeli çocuklar ilginç bir yöntemle kendilerini körfezin serin sularına bıraktılar" (16.08.2017, Hürriyet). Pet şişelerle kendilerini güvenliğe almaya çalışarak yüzen mülteci çocuklardan bir tümevarıma gidilmiş ve mültecilerin hazin sonlarının algısı tekrar haberin içindeki bilgi cümleleriyle pekiştirilmeye çalışılmıştır. 
Mültecilere yapılan yardım haberleri ön plana çıkarılmaya çalışılmıştır. Bu haberlerde Türk halkının dostluğu, vefası ve hoşgörüsü kavramlar olarak hatırlatılmıştır.

Tablo 7. Mültecilere yapılan Yardımlarla İlgili Haber Örnekleri

\begin{tabular}{|l|l|}
\hline BAŞLIKLAR & $\begin{array}{l}\text { GAZETELERİN İNTERNET } \\
\text { SİTELERINDE HABERLERİN } \\
\text { YAYINLANDIĞI TARİH }\end{array}$ \\
\hline Mülteciler Yalnız Değil & 10 AĞUSTOS 2017, Hürriyet \\
\hline $\begin{array}{l}\text { Sokakta Yaşayan 9 Kişilik Afgan } \\
\text { Aileye Esnaf Destek Oldu }\end{array}$ & 15 AĞUSTOS 2017, Hürriyet \\
\hline $\begin{array}{l}\text { El Ele Vererek Mülteci Çocuklara } \\
\text { Türkçe Öğretiyorlar }\end{array}$ & 31 TEMMUZ 2017, Hürriyet \\
\hline Mülteci Aileler Yaşama Tutundu & 09 TEMMUZ 2017, Hürriyet \\
\hline
\end{tabular}

Hürriyet gazetesindeki yardım haberlerinin bazılarında, alt satırlarında mültecilerin dilinden sorunlar dile getirilmiş ve devletin mülteci politikasındaki yetersizliği vurgulanmıştır. Ancak aynı dönemde Sabah gazetesinin internet sitesinde bu tarz bir eleştiriye rastlanmamıştır: "Sokakta yaşayan 9 kişilik Afgan aileye esnaf destek oldu" haberinin metin bölümünde Afgan Noori “Zonguldak' ta ev ve iş bulamadık. Bir haftadır parklarda yatıyoruz. Türkçe bilmiyoruz. Türk halkının bize yardım edeceklerini düşünerek geldik. Fakat düşündüğümüz gibi olmadı. Vatandaşın sayesinde geçici olsa da bir eve yerleştik." demiştir. Aynı haberde yardımda bulunan esnaf ise "Devletimizin mercilerini arıyoruz ama emniyet bir şey yapamayacaklarını söyledi. Göç idaresi de bir şey yapamıyoruz. Bekleyecekler, mülteci konumundalar diyor. Şimdi bu insanlar ne olacak... Bu insanlara yardım edilmesi için devletimizden ve vatandaşlarımızdan yardım bekliyoruz" demiştir (15.08.2017, Hürriyet). "Suriye sanat kampı" haberinde röportaj yapılan Suriyeli sanatçı "Eğitimli Suriyeliler için İstanbul'da düzgün iş bulmak ve yaşam kurmak çok zor. Suriyeli olarak resimleri Türkiye'de satmak çok zor, Avrupa'da satıyorum" (23.07.2017, Hürriyet) demiştir.

Mültecilerin başarıları da bazı haberlerin içeriğini oluşturmuştur. Hürriyet gazetesi internet sitesinde bu haberlerin genelde diş kaynaklı olduğu gözlenmiştir. 
Tablo 8. Mültecilere İlişkin "Başarı” Haberleri

\begin{tabular}{|l|l|}
\hline BAŞLIKLAR & $\begin{array}{l}\text { GAZETELERIN İNTERNET } \\
\text { SİTELERINDE HABERLERİ } \\
\text { YAYINLANDIĞI TARİH }\end{array}$ \\
\hline Afgan Mültecinin Rekor Denemesi & 03 TEMMUZ 2017, Hürriyet \\
\hline $\begin{array}{l}\text { Berlin'in Yeraltı Krallı̆̆ında Bir } \\
\text { Mülteci Süper Star }\end{array}$ & 29 TEMMUZ 2017, Hürriyet \\
\hline Afgan Kökenli Viking & 01 AĞUSTOS 2017, Hürriyet \\
\hline
\end{tabular}

Sabah gazetesi ise yurtdışından yansıttığı haberinde mültecinin mağduriyetini dile getirmiştir. Haberde Almanya'da bir hâkimin koyduğu yasakla başörtülü mültecinin boşanma davasının duruşmasına giremeyeceğini şu başlıkla vermiştir: "Hâkim, başörtülü davacıyı istemedi" alt başlıkta ise "Hak ve özgürlükler zedelendi" demiştir. Sabah gazetesi yurtdışındaki mülteci haberine, iktidarın değerlerine, ideolojisine yakın bir bakış açısıyla yaklaşmıştır.

Hürriyet gazetesinde toplumsal gerilim temalı haberlere baktığımızda şu başlıklara ve spotlara rastlamaktayız:

Başlık/ Plajdaki kadınların fotoğrafını çeken Suriyelilere linç girişimi (3.07. 2017, Hürriyet).

Spot/ Samsun'da serinlemek için denize giren kadınların fotoğraflarını çektiği iddia edilen Suriye uyruklu 2 genç, linç edilmekten polis tarafından kurtarıldı (3.07. 2017, Hürriyet).

Aynı gün Hürriyet gazetesi internet sitesinde "gerilim" temalı ikinci bir haber daha yayınlanmıştır:

Başlık/ Büyükçekmece Belediye Başkanı'ndan Suriyelilere plaj uyarısı geldi (3.07.2017, Hürriyet).

Spot/ Büyükçekmece Belediye Başkanı Hasan Akgün, denizden yararlanmak için ilçe sahiline gelen bazı Suriyelilerin hafta sonları etik olmayan davranışlarda bulunduklarını belirterek

"Misafirlerimizin ev sahibine saygı duyarak hayatlarını idame ettirmelerini bekliyoruz. Aksi takdirde yaşanabilecek huzursuzluklarda en büyük zararı mülteci kardeşlerimiz görecektir. Çünkü toplumumuz onlara karşı hoşgörüsünü kaybedecektir" (3.07.2007, Hürriyet). Aynı haberin alt satırlarında mültecilerin parklara ve kent mobilyalarına zarar verdikleri, uygun kıyafetle denize girmeleri ve sahilde mangal yakmamaları konusunda uyarıldıkları belirtilmiştir. Burada 
yine basının kullandığı "Suriyeli" söylemiyle sığınmacılar kimliksizleştirilmiş ve belli bir grubun üyesi haline getirilmiştir. Suriyeli şiddet, uyumsuzluk ve kaosla özdeş kılınmaktadır. Medya bu söylemlerle kamuoyunda mültecilerin sadece ekonomik değil "sosyal bir yük" olduğu algisını da üretmektedir. Medya ve etnik çeşitlilik uzmanı Charles Husband bu durumu şöyle özetler: "Nefret söylemi öncelikle bir grup hareketi. Karşıdaki kişinin insani özelliklerini yok ederek onu bir birey değil, nefret edilen bir grubun bütün kötü özelliklerini taşıyan bir örneklem olarak gösteriyor" (www.nefretsoylemi.org).

03 Temmuz 2017'de çıkan haberlerin ardından, ertesi gün Hürriyet internet sitesinde bir başka "gerilim" temalı haber daha satırlara yansımıştır:

Başlık/ Tehlikeli tırmanış (4.07.2017, Hürriyet).

Spot/ Başkentte önceki akşam Suriyeli mültecilerle çıkan ve 1 kişinin yaralandığg kavga sonrası mahallede gerilim arttı. Suriyeli mülteci ve Irak Türkmenlerine ait işyerlerine zarar verilirken, Türk gençler de olayların başladığı iddia edilen park önünde gün boyu nöbet tuttu. (4.07.2017, Hürriyet).

Ertesi gün, 05 TEMMUZ 2017'de benzer içerikli bir haber Hürriyet internet sitesinde yine yer almıştır:

Başlık/ Başkanlar uyarıyor (5 Temmuz 2017, Hürriyet).

Spot/ Mültecilerin karıştığı son gerginliğin yaşandığı Yenimahalle ile Suriyelilerin Başkent'te en yoğun yaşadığ 1 ilçe olan Altındağ belediye başkanları uyardı: "Ruhsatsız işyerleri sorun yaratıyor, 25 kişinin bir evde kalması problem çıkarıyor. Yardımlar sorunu çözmez entegrasyon şart" (5.07.2017, Hürriyet).

Haberin ilerleyen satırlarında verilen Altındağ Belediye Başkanı'nın röportajındaki "yardımlar yapılırken, insanımızın hassasiyetleri göz ardı edilmemeli, mülteci olarak gelen vatandaşların da mülteci olduklarını bilmeleri lazım” sözlerine yer verilmiştir (5.07.2017, Hürriyet).

Hürriyet'in verdiği bu "gerginlik" temalı haberde kullanılan "son" kelimesi bunun ilk olmadığını daha önceleri de Suriyelilerle bazı ilçelerde yerel halkın sorun yaşadığını vurgulamakta, kamuoyundaki "Suriyeliler ve çatışma algısını" güçlendirmektedir. Belediye başkanı ise açıklamasıyla öncelikle Suriyelilerle ilgili bazı sorunları dile getirmiştir: evlerde çok kalabalık yaşamaları, ruhsatsız açılan dükkânlar ve bunların ucuza mal satarak yarattıkları haksız rekabet, yerel halktan kadınların yürürken ya da spor yaparken rahatsız edilmeleri vb. Belediye başkanı bu şikâyetlerin ardından "mülteci olduklarını bilmeleri lazım" diyerek, Suriyelileri kastederek bir anlamda "misafir misafirliğini bilmeli, ev sahibini rahatsız etmemeli" mesajını vermektedir. Özetle başlangıçtaki "misafirperverlik" söylemi süreç içerisinde bir anlamda "istilacı" "ötekiler" kavramlarına 
dönüşmüştür. "Durkheim tarafindan formüle edilen 'günah keçisi' kuramı, yoksunluk-saldırganlık-yansıtma sıralamasını kapsayan varsayıma dayanır. Yoksunluk, saldırganlık duyguları yaratır, saldırganlık ise savunmasız günah keçilerine yönelir. Bu sırada uygulanan şiddet daha sonra, olumsuz yargilar ve stereotiplerle akılcı hale getirilir ve doğrulanır" (Schnapper, 2005:137). Bu tanımı açmak gerekirse, mültecilerin geldikleri ülkede neden olduğu ucuz işgücü yüzünden yaşanılan iş kayıpları veya evlere olan talep yüzünden ev kiralarının artması gibi yoksunluğu ortaya koyan ekonomik etkenler saldırganlık duygularını pekiştirip bu gruba tavır alınmasına neden olabilmektedir.

Hürriyet bu haberleri yayınlarken, Sabah gazetesinin bu haberleri vermemiş, tam tersine çıkan gerginlik haberlerini ağır bir dille eleştirmiştir:

Başlıklar/ "Bu mesajlara sakın inanmayın" "Yalanın Daniskası", "Kara propaganda ak1l almaz boyutlara ulaştı" (6.07. 2017, Sabah).

Haberin girişinde "Suriyeliler ile gerginliğin altından, yine sosyal medya üzerinden yayılan yalan haberler çıktı. Akıl almaz hikâyeler üreten kara propaganda odakları bu kadarına pes dedirtti." Haberde iktidarın mültecilere verdiği iddia edilen ekstra haklar/avantajlar yalanlanmıştır. Ayrıca aynı haber içerisinde İçişleri Bakanlığı'nın "Gerginlikler iç siyaset malzemesi haline getiriliyor" ifadesi yer almıştır (5.07.2017, Sabah). Haberde hükümet yetkililerinin yaptığı Suriyeliler ile ilgili açıklamalar verilmiş ve suç oranlarında azalma olduğu bilgisi aktarılmıştır.

Araştırmaya konu olan dönemde, medyada çıkan gerginlik haberlerinin ardından 07 TEMMUZ 2017'de Sakarya'da yaşayan Suriyeli mülteci hamile bir kadın ve on aylık bebeği iki Türk tarafindan öldürülmüş, bu konu tüm gazetelere günlerce yansımıştı. Bu durum medyanın içinde de eleştirilerin odağına oturmuş, Sabah gazetesi Doğan Medya Grubuna bağlı DHA'nın (Doğan Haber Ajansi) geçtiği haberdeki üslubu şiddetle eleştirmiş, üstelik bu haberden de yola çıkarak Hürriyet gazetesinin son zamanlarda yaptığı haberleri "irkçılık" ve "dışlayıcı" olmakla suçlamıştı (8.07.2017. Sabah).

Eleştirilere konu olan DHA'nın 7.07.2017 tarihinde habere yansıyan satırları şu şekildeydi: "Birol K. ve Cemal B'nin Halid Al-Rahmun ile aynı tavuk kesimhanesinde çalıştıkları birkaç gün önce aralarında kimin daha fazla çalıştığı konusunda tartışma çıktığı öğrenildi. Ancak, öldürülen Suriyeli kadının güzelliği ile dikkat çektiği, komşusu olan Birol K'nin bu nedenle olayı gerçekleştirmiş olabileceği öğrenildi” (www.m.f5haber.com). 
Ajansın geçtiği bu haber, gelen eleştirilerin ardından düzeltildi. Ancak durum Sabah gazetesi internet sitesinden ağırlaşan bir üslupla devam etti.

Başl1k/ "Vahşetin Suç ortağı kim?" (8.07.2017, Sabah).

Sabahın aynı haberinin alt başlıklarında ise:

"Irkçı söylemlere tepki"

"Medyada nefret dili"

"Bu Nas1l Kafa"

"Doğan Medyası ve Sözcü nefrete suç ortağı"

"Suriyeli kardeşlerimizi hedef gösterenlerin Suriye'deki zalim rejimden farkı yok" denilmiştir (8.07.2017, Sabah).

Sabah'ın haberinin ilerleyen satırlarında ise: "Suriyelilerin suç profillerinin öne çıkarıldı̆̆ı haberlerin bayraktarlığını Doğan Medya Grubu yapıyor", "Hürriyet, DHA, Sözcü ve Cumhuriyet'te sistematik Suriyelileri dışlayan ve rrkçılık içeren haberler yapiyorlar" (8.07.2017, Sabah).

Doğan Haber Ajansının haberle ilgili ilk söylemi, cinsiyetçi bir zemine oturmuş, cinsiyetçi yaklaşımdan da öte kadının güzel olması bir tahrik unsuru gibi gösterilmiş tecavüz suçuna bir gerekçe yaratma gayretine girilmiş gibi bir algı yaratmaktadır. Özetle ağır bir suçu hafifleten bir nedenselliğe bürünmüştür. Sabah gazetesinin ise eleştirel söylemlerini yaparken, bir olaydan yola çıkarak tüm iktidara muhalif gazeteleri aynı potaya koyduğu, "1rkçılıkla" tüm bu gazeteleri suçladığı, okuyucunun gözünde bu medya organlarını olumsuzlaştırdığ 1 gözlenmiştir. Sabah gazetesi "Suriyeli kardeşlerimizi hedef gösterenlerin Suriye'deki zalim rejimden fark1 yok" derken "mağdur Suriyeli" kavramı "din kardeşliği” algısı üzerinden pekiştirilmiştir.

Sabah gazetesi tarafından "nefret suçu" işlemekle itham edilen Hürriyet gazetesi, Hollanda' daki mülteci haberini internet sayfasına şu satırlarla taşımıştır, ancak aynı habere Sabah gazetesinde rastlanmamıştır:

Spot/ Hollanda'da mültecilere zorunlu yüzme dersi önerisi (9.08.2017, Hürriyet). Haberde ise: "Hollanda'da 'Suriyeli mülteci havuzda battı' başlıklı haberde "16 yaşındaki Suriyeli, yüzme havuzunu ziyaret eden birçok kişinin keyfini kaçırarak kötü bir gün yaşattı" ifadesi urkçılık suçlamalarına neden oldu" denmektedir. Hürriyet internet sitesi PowNed gazetesi genel yayın yönetmeninin haber nedeniyle özür dilediğini ve haberin yayından kaldırıldığı bilgisini satırlarına taşımıştır (9.08.2017, Hürriyet). 


\section{Art Alan ve Bağlam Bilgisinin Sunumu}

Bu bölüm haberlerin arka planını anlatmakta, söylem çözümlemesinin önemli aşamalarından biridir. Olayların bağlantılı olduğu tarihsel süreç ve toplumsal durumları içerir. Çözümleme kapsamındaki haber içeriği şöyledir:

“...k1y1ya vuran mülteci cesetleri gündemden düşmezken, çoğu yüzme bilmeyenlerin umut yolculuğu genelde kötü haberlerle sonlanırken, İzmir'de yaşayan Suriyeli çocuklar ilginç bir yöntemle kendilerini körfezin serin sularına biraktılar" (16.08.2017, Hürriyet).

Çözümlenen tarih aralığındaki haberlerde genel olarak "art alan" bilgisine pek rastlanmamıştır. Haberler genel olarak "bağlam bilgisi" ekseninde çerçevelenmektedir. Tarihsel geçmişin olmaması sığınmacıların daha anlaşılabilir olmalarını, sorunlarının daha detaylı kamuoyuna aktarılmasını engellemektedir.

\section{Haberin Kaynakları ve Tarafların Değerlendirmeleri}

İncelenen her iki gazetenin internet sitesindeki haberlerde farklı haber kaynaklara rastlanmıştır. Bu, bazen bir muhabir, bazen bir ajans, bazen bir hükümet yetkilisi, bazen de yapılan bir araştırma olmuştur. Haberde söylemi kuvvetlendirmek için seçilen haber kaynaklarından örnekler şu şekildedir:

"Devletimizin mercilerini arıoruz ama emniyet bir şey yapamayacaklarını söyledi. Göç idaresi de "bir şey yapamıyoruz, bekleyecekler, mülteci konumundalar" diyor. Şimdi bu insanlar ne olacak... Bu insanlara yardım edilmesi için devletimizden ve vatandaşlarımızdan yardım bekliyoruz" (15.08.2017, Hürriyet). Hürriyet gazetesinin bu haberinde Afgan bir aileye yardım eden esnafin röportajına yer verilmiştir. Bir başka haberde ise Suriyelileri sosyal bir yük olarak tanımlayan ve şiddetle özdeşleştiren muhalif bir siyasetçinin sözleri yer almıştır: CHP'li Toprak "1.5 milyon çocuk ve genç Suriyeli topluma kazandırılamazsa, suç örgütleri, terör örgütleri için insan kaynağı olmaya, toplum için sosyal mayınlara dönüşmeye aday" (3.08.2017, Hürriyet).

"Suriyelilerin karıştıkları olayların Türkiye'deki toplam asayiş olaylarına oranı 2014-2017 arasında yıllık ortalama yüzde 1,32'dir" (6.07.2017, Sabah). Sabah ise İçişleri Bakanlığı'nın bu açıklamasına yer vererek görüşüne resmiyet kazandırmak, "şiddet" "gerilim" haberlerini yapanlara karşı söylemini güçlendirmek istemiştir. 


\section{SONUÇ}

Sığınmac1-mülteci-göçmen, Türkiye'nin de içinde bulunduğu, ağır yaşam koşullarının hüküm sürdüğü coğrafyanın gündeminden düşmeyen terimlerdir. Hepsinin Türk hukuk sistemindeki statüsü birbirinden farklıdır, ancak yaşanılan zorluklar ortaktır.

2011 yılında Suriye'de başlayan savaşın ardından Türkiye'ye gelen Suriyeli sığınmacıların "misafirlik" kelimesiyle başlayan yolculukları, Suriye'deki karışıklığın bitmeyen bir iç savaşa dönüşmesiyle uzun bir hal almış ve Türkiye'nin "hoşgörü", "misafirperverlik" kelimeleriyle karşıladıkları bu insanların "misafirliği" gün geçtikçe sorgulanır bir nitelik kazanmıştır. Bu durum ana akım medyaya da farklı söylemlerle yansımıştır. Artık "gidici" tanımlaması yerine "kalıcı" ama "nasıl kalıcı" tartışmaları başlamıştır.

Medyanın gündem belirleme gücü, olaylara çizdiği çerçeve, haberleri veriş sıklı̆̆ 1 ve aktardığı söylemin kamuoyunun algısını etkilemekte olduğu bilinmektedir. Analiz etmek için seçilen tarih aralığında medyanın mülteci meselesini kamuoyuna nasıl aktardığı, hangi konuyu ne kadar sıklıkla ele aldığı/almadığ 1 incelenmiştir. Çalışmada 1.07.2017 ile 17.08.2017 tarihleri arasında Hürriyet gazetesinin internet sitesindeki ve Sabah gazetesinin internet sitesindeki mültecisığınmacı- göçmen temalı haberler irdelenmiştir. Bu haberler içerik analizi ve Van Dijk'in söylem analizi yöntemiyle ele alınmıştır. İncelenen dönemde Hürriyet'in internet sitesinde mülteci-sı̆̆ınmacı-göçmen içerikli 51 habere, Sabah internet sitesinde ise 17 habere rastlanmıştır.

Analiz edilen dönem sonunda Hürriyet gazetesinin "mültecileri” özellikle "Suriyeli" kavramını sıklıkla internet sitesine taşıdığı gözlenmiştir. Ancak her türlü haber yapmasına rağmen mültecileri olumlamayan içerikte "sosyal yük" "ekonomik yük" ekseninde gördügü tespit edilmiştir. Sabah gazetesi ise "Suriyeli" kavramını "mağdur-gariban" kelimesi üzerinden inşa etmiştir. Hürriyet internet sitesinde yayınlanan Suriyelilerle yerel halk arasında yaşanan gerginlik haberlerine Sabah gazetesi internet sitesinde rastlanmamıştır, özetle Sabah gazetesi Suriyeliler ile Türkiyeliler arasındaki gerilim ve çatışmaları haberlerine yansıtmamıştır. Tam tersine Sabah gazetesi diğer ana akım medya organlarında çıkan bu tarz haberlerin "medyada nefret dilini" körüklediğini belirtmiş, hatta bu haberleri yapan medya gruplarını "1rkçı haberler" yapmakla suçlamıştır. Sabah gazetesinin incelenen dönem içinde meydana gelen Iraklılarla ilgili cinsel istismar ve taciz haberini sitesine taşıdığ ama özellikle Suriyelilerle ilgili hiçbir eleştirel ya da adli bir haber yapmadığı gözlenmiştir. 


\section{KAYNAKÇA}

Fairclough, Norman (2001) Language and Power, Longman.

Dijk, T.V. (2005). "Söylemin Yapıları ve İktidarın Yapıları" Medya, Iktidar, İdeoloji, Mehmet Küçük (çev.). Ankara: Bilim ve Sanat

Efe, İbrahim (2015) Türk Basınında Suriyeli Sığınmacılar (Rapor). İstanbul: Seta Yayinlarl

Schnapper, Dominique, (2005). Sosyoloji Düşüncesinin Özünde Öteki ile İlişki. Ayşegül Sönmezay (çev.). İstanbul: İstanbul Bilgi Üniversitesi Yayınları

Şen, Fulya (2016). "Eleştirel Medya Çalışmalarında Kültürel Çalışmalar Perspektifi: Medya, İdeoloji ve Temsil ". Eleştirel Medya Çalışmaları, Meltem Bostanci (haz.). İstanbul: Anahtar Kitaplar Yayınevi

Tarhan, Dilek (2016). "Suriye Iç̧ Savaşında Yaşanan Olayların Eleştirel Söylem Analizi Yöntemi Ile Incelenmesi: CNN Türk ve CNN International Haber Kanallarının Karşılaştırmalı Analizi”. Eleştirel Medya Çalışmaları, Meltem Bostancı (haz.). İstanbul: Anahtar Kitaplar

\section{INTERNET KAYNAKLARI}

www.akademikperspektif.com/2015/02/23/turkiyedeki-suriyelilerin-hukuki-

statusu-uzerine-bir-calismal

http://www.ankarabarosu.org.tr/siteler/ankarabarosu/hgdmakale/2014-2/31.pdf

$\underline{w w w . b b c . c o m}$

www. cocukvakfi.org.tr

www.danistay.gov.tr

$\underline{w w w . d w . c o m}$

www.igamder.org

www.ozgurlukarastirmalari.com/pdf/rapor/OAD_c2lGWsK.pdf

www.m.f5haber.com

www.nefretsoylemi.org

www.tgc.org.tr 